\title{
Pemberdayaan Kader Kesehatan Gigi Dan Mulut Dalam Program "Sikap" Di Dusun Pendul
}

\author{
Afina Hasnasari Heningtyas ${ }^{*}$, Sri Utami², Novitasari Ratna Astuti ${ }^{3}$ \\ ${ }^{1 * 2,3}$ Program Studi Kedokteran Gigi, Fakultas Kedokteran dan Ilmu Kesehatan, Universitas Muhammadiyah Yogyakarta \\ Jl. Brawijaya, Tmantirto, Ksihan, Bantul, Yogyakarta \\ Email: afinahasnasari@gmail.com \\ DOI: 10.18196/ppm.39.101
}

\begin{abstract}
Abstrak
Indeks karies DMF-T Provinsi DIY tahun 2013 sebesar 5,9 (kategori tinggi) dengan effective medical demand sebesar 10,3\%. Dengan adanya keterbatasan tenaga medis dan fasilitas kesehatan, upaya promotif dan preventif dapat dilakukan dengan cara pemberdayaan masyarakat dengan melibatkan kader kesehatan. Pemberdayaan masyarakat ini memiliki tujuan pemberdayaan dan penerapan pelatihan indeks DMF-T bagi para kader kesehatan gigi dan mulut Dusun Pendul. Metode yang dilakukan adalah metode experiential learning dengan jenis program logic model yang menjelaskan tahapan dalam mengimplementasikan sebuah program, mulai dari input, output, outcomes, dan goal dari program yang akan dicapai. Para kader yang sudah dilatih sebelumnya melakukan pemeriksaan karies gigi di komunitas, yaitu pada semua anggota keluarga masing-masing kader dengan menggunakan indeks DMF-T. Hasil pengukuran indeks karies DMF-T yang dilakukan oleh para kader di Dusun Pendul diperoleh data bahwa mean DMF-T pada laki-laki lebih tinggi dibandingkan pada wanita, mean DMF-T tertinggi pada umur 41-50 tahun, dan mean DMF-T terendah pada umur 21-30 tahun. Data tersebut menunjukkan bahwa ada faktor risiko tertentu yang menyebabkan tingginya angka indeks DMF-T berdasarkan jenis kelamin dan umur. Kesimpulan dari pemberdayaan ini adalah data hasil pemeriksaan oleh kader kesehatan Dusun Pendul merupakan data yang terukur dan valid. Pelatihan yang diberikan sebelumnya memberikan hasil yang maksimal.
\end{abstract}

Kata Kunci: Kader kesehatan gigi mulut, Indeks DMF-T

\section{Pendahuluan}

Provinsi Daerah Istimewa Yogyakarta (DIY) pada tahun 2013 memiliki prevalensi penduduk yang mempunyai permasalahan gigi dan mulut sebesar $32,1 \%$, penduduk yang menerima perawatan dari tenaga medis gigi $31,9 \%$, dan effective medical demand (EMD) sebesar $10,3 \%$. Gambaran tingkat keparahan kerusakan gigi permanen atau Indeks DMF-T Provinsi DIY pada tahun 2013 sebesar 5,9 yang dapat dikategorikan tinggi melebihi indeks kerusakan gigi DMF-T secara nasional sebesar 4,6 (Kemenkes RI, 2013). Penyebaran sumber daya tenaga kesehatan, terutama dokter gigi yang bekerja di Puskesmas Kabupaten Bantul, sejumlah 37 orang (Kemenkes RI, 2017). Hal tersebut menunjukkan bahwa jumlah tenaga medis masih rendah. Hidayat dkk. (2016) berpendapat bahwa potensi masyarakat dapat dilibatkan dalam usaha promotif dan preventif karena adanya keterbatasan tenaga medis dan fasilitas tenaga kesehatan yang masih rendah.

Potensi masyarakat yang dapat dilibatkan dalam usaha promotif dan preventif adalah kader kesehatan. Pendidikan kesehatan merupakan salah satu upaya promotif dan preventif untuk menyampaikan pesan kesehatan kepada masyarakat, kelompok, atau individu dengan harapan dapat menambah pengetahuan kesehatan yang lebih baik (Kidd dan Bechal, 1991). Salah satu sasaran di bidang kesehatan dari promosi kesehatan adalah pemberdayaan masyarakat. Masyarakat merupakan sasaran primer yang harus diberdayakan sehingga mereka dapat memelihara dan meningkatkan kesehatan (Notoatmodjo, 2007).

Potensi masyarakat untuk menjadi kader kesehatan gigi dan mulut dapat menjadi salah satu upaya untuk menjaga kebersihan mulut yang efektif serta mejadikannya sebuah kebiasaan karena para kader dapat menyampaikan kepada masyarakat (Hidayat dkk., 2016). Pendidikan, umur, banyaknya pengetahuan yang diberikan dari sumber yang jelas adalah salah satu faktor yang memengaruhi pengetahuan kader kesehatan (Adistie dkk., 2017). Pengetahuan pendidikan 
kesehatan gigi dan mulut pada kader diharapkan dapat meningkatkan derajat kesehatan mulut masyarakat pada saat ini (Herjulianti dkk., 2001). Dari survei pendahuluan yang dilakukan pada akhir tahun 2017 dan program pelatihan kader kesehatan gigi dan mulut tahun 2019 ditemukan beberapa permasalahan, antara lain akses pelayanan kesehatan gigi dan mulut yang belum optimal, kegiatan atau program kesehatan gigi dan mulut (kesgilut) puskesmas belum menjangkau wilayah Dusun Pendul karena adanya keterbatasan tenaga kesehatan, tingginya status karies gigi masyarakat, dan kurangnya kesadaran perilaku kesgilut masyarakat. Hal ini ditambah dengan belum tersedianya data status karies gigi masyarakat sebagai pijakan dalam menentukan program intervensi yang tepat sasaran. Program kesgilut oleh masyarakat dan pihak terkait (kecamatan dan puskesmas) yang tepat sasaran dan berbasis data serta prioritas masalah belum ada. Pengabdian masyarakat ini memiliki tujuan pemberdayaan dan penerapan pelatihan indeks DMF-T bagi para kader kesehatan gigi dan mulut Dusun Pendul.

\section{Metode Pelaksanaan}

Metode yang digunakan dalam pemberdayaan dan penerapan pelatihan indeks DMF-T bagi kader kesehatan gigi dan mulut Dusun Pendul adalah dengan metode experiential learning, yaitu metode yang memberikan peningkatan keterampilan di masyarakat dan peningkatan kesadaran tentang proses penyakit yang memengaruhi keluarga (Dornan and Bundy, 2004). Metode ini terdiri atas proses pendekatan pembelajaran yang meliputi service learning. Service learning digunakan untuk menggambarkan pembelajaran dengan memberi kesempatan untuk memperoleh dan menerapkan pengetahuan juga keterampilan yang telah diajarkan sebelumnya. Pemberdayaan kader kesehatan gigi dan mulut ini dilakukan dalam program "Sikap" (Sehat Gigi Ibu-ibu Kader Pendul), yaitu program Ibu-Ibu kader kesehatan gigi dan mulut Dusun Pendul untuk mengaplikasikan cara pengukuran status karies gigi dengan menggunakan indeks DMF-T di lingkungan keluarga/RT/RW Dusun Pendul. Para Kader tersebut melakukan pengukuran indeks DMF-T kepada seluruh anggota keluarga masing-masing dengan menggunakan alat diagnostik dan APD berupa masker dan handscoon serta bahan sterilisasi alat berupa alkohol dan kapas. Hasil pengukuran indeks kemudian dicatat dan direkap oleh para kader pada formulir rekap yang sudah disediakan. Berikut merupakan rincian kegiatan pemberdayaan masyarakat.

1. Lokasi kegiatan : Rumah para kader kesehatan gigi dan mulut Dusun Pendul

2. Waktu kegiatan : bulan Juli 2020

3. Rincian kegiatan: Tabel 1.

Tabel 1. Rincian Kegiatan Pemberdayaan Masyarakat

\begin{tabular}{llcl}
\hline No & \multicolumn{1}{c}{ Hari dan Tanggal } & $\begin{array}{c}\text { Jumlah } \\
\text { (Hari) }\end{array}$ & \multicolumn{1}{c}{ Kegiatan } \\
\hline 1 & 12 Juli 2020 & 1 & Sosialisasi kegiatan \\
\hline 2 & 19 Juli 2020 & 1 & $\begin{array}{l}\text { Simulasi pemeriksaan indeks DMF-T serta pembagian alat bahan dan formulir } \\
\text { pemeriksaan Indeks DMF-T }\end{array}$ \\
\hline 3 & 20-31 Juli 2020 & 12 & Pemeriksaan indeks DMF-T oleh para kader kesgilut \\
\hline 4 & 10 Agustus 2020 & 1 & Pengumpulan hasil pemeriksaan (formulir pemeriksaan dan rekap data) \\
\hline
\end{tabular}

a. Pengukuran indeks karies DMF-T oleh para kader kesehatan gigi mulut 


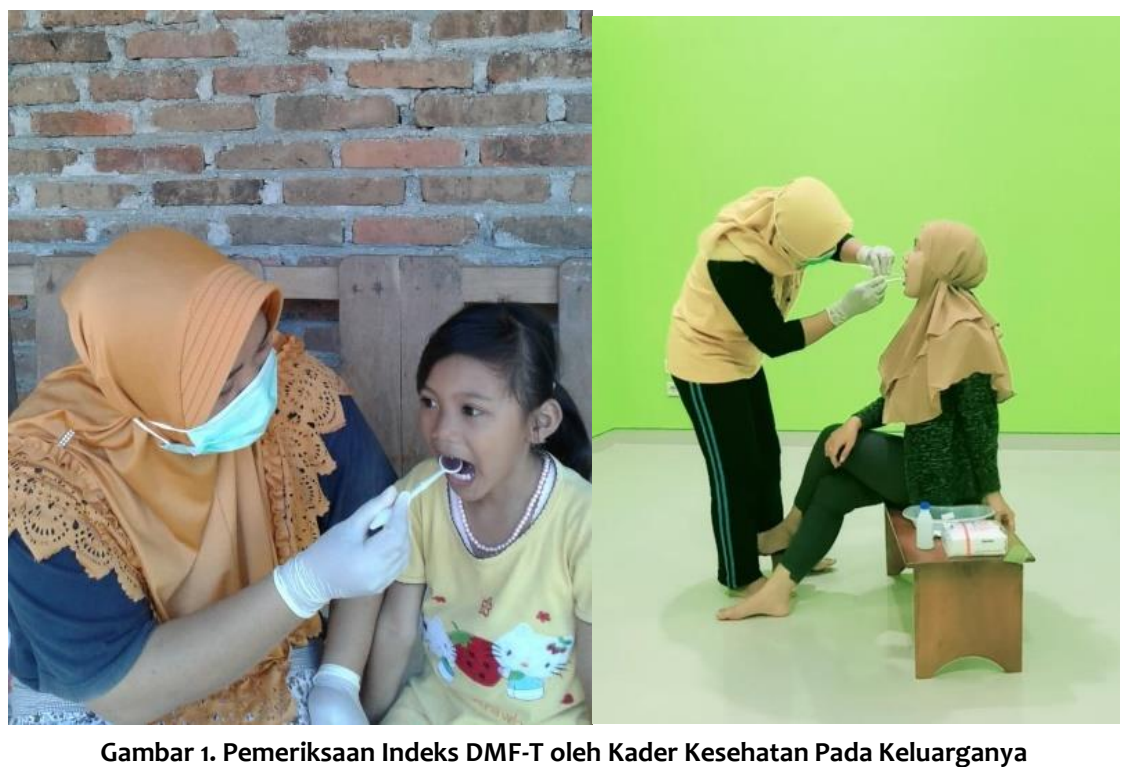

Kegiatan praktik kerja/keterampilan kader (gambar 1.) dilakukan di rumah keluarga kader masing-masing dengan melibatkan kader yang telah dilatih untuk mengetahui status karies masing-masing anggota keluarga dengan mengukur indeks karies DMF-T. Kegiatan ini dilakukan pada tanggal 20-31 Juli 2020.

\section{Hasil dan Pembahasan}

\section{Pelatihan kader kesehatan gigi dan mulut}

Pelatihan kader kesehatan dilakukan pada tanggal 19 Juli 2020 di kediaman Kepala Dukuh Dusun Pendul. Kegiatan ini diikuti oleh seluruh kader kesehatan Dusun Pendul yang berjumlah empat belas orang. Pelatihan kader dilakukan dengan memberikan bekal pengetahuan dan keterampilan mengukur status karies dengan pemeriksaan indeks karies DMF-T. Hal ini merupakan upaya untuk meningkatkan kesadaran dan perilaku kesehatan gigi dan mulut masyarakat, khususnya lingkup keluarga, serta memberikan data status karies gigi keluarga di wilayah Dusun Pendul. Pada saat pelatihan, para kader tampak sangat antusias. Hal ini terlihat dari aktifnya para kader ketika sesi tanya jawab dengan tim pengabdi. Kader kesehatan juga datang dengan memakai seragam kader. Hal ini menunjukkan kekompakan kader kesehatan Dusun Pendul. Para kader juga terlihat antusias dalam proses simulasi pemeriksaan di model gigi.

\section{Pemeriksaan status karies gigi menggunakan indeks DMF-T}

Hasil pengukuran indeks DMF-T oleh para kader dapat dilihat pada tabel-tabel berikut.

\begin{tabular}{cccccc}
\multicolumn{6}{c}{ Tabel 2. Mean DMF-T Berdasarkan Jenis Kelamin Responden } \\
\cline { 2 - 3 } Jenis Kelamin & \multicolumn{2}{c}{ Jumlah (n) } & DMF-T & \multirow{2}{*}{ Mean } \\
\cline { 2 - 3 } & $(\mathrm{n})$ & $\%$ & & \\
\hline Laki-laki & 17 & 45,9 & 69 & 4.06 \\
\hline Perempuan & 20 & 54,1 & 40 & 2.00 \\
\hline
\end{tabular}

Tabel 2 menunjukkan bahwa mean DMF-T pada laki-laki lebih tinggi dibandingkan pada wanita, yaitu sebesar 4,06. Tabel 2 juga menunjukkan bahwa responden yang diperiksa lebih banyak berjenis kelamin perempuan, yaitu sebesar $54,1 \%$. 
Tabel 3. Mean DMF-T Berdasarkan Umur Resonden

\begin{tabular}{cccccccc}
\hline \multirow{2}{*}{$\begin{array}{c}\text { Umur } \\
\text { (Tahun })\end{array}$} & \multicolumn{2}{c}{ Jumlah } & \multicolumn{3}{c}{ Indeks DMF-T } & DMF-T & Mean \\
\cline { 2 - 5 } & $(\mathrm{n})$ & $\%$ & $\mathrm{D}$ & $\mathrm{M}$ & $\mathrm{F}$ & & 2.67 \\
\hline $1-10$ & 6 & 16,2 & 16 & 0 & 0 & 16 & 1.75 \\
\hline $11-20$ & 12 & 32,4 & 20 & 0 & 1 & 21 & 1.50 \\
\hline $21-30$ & 4 & 10,8 & 3 & 0 & 3 & 6 & 2.00 \\
\hline $31-40$ & 4 & 10,8 & 8 & 0 & 0 & 8 & 5.60 \\
\hline $41-50$ & 5 & 13,5 & 19 & 2 & 7 & 28 & 5.00 \\
\hline $51-60$ & 6 & 16,2 & 20 & 10 & 0 & 30 & \\
\hline
\end{tabular}

Tabel 3 menunjukkan bahwa mean DMF-T paling tinggi adalah 5,6, yaitu pada kelompok umur 41-50 tahun, sedangkan mean DMF-T paling rendah adalah 1,50, yaitu pada kelompok umur 21-30 tahun. Tabel 2 dan tabel 3 menunjukkan bahwa aplikasi pelatihan kader yang pernah diberikan telah memberikan hasil yang terukur dan valid. Data status karies gigi berupa indeks DMF-T dari 37 responden telah dihasilkan dengan baik dan benar.

Adapun pengabdian masyarakat yang melibatkan kader kesehatan gigi dan mulut Dusun Pendul ini menerapkan metode experiential learning. Metode ini merupakan perpaduan teori dan praktik serta melibatkan pertemuan langsung dengan fenomena yang diteliti, bukan hanya berpikir tentang pertemuan tersebut atau hanya mempertimbangkan kemungkinan melakukan sesuatu tentang hal tersebut (Borzak, 1981). Pelatihan yang diadakan untuk kader, tidak hanya pemberian teori kesehatan gigi dan mulut, seperti cara menggosok gigi yang benar dan cara melakukan pemeriksaan DMF-T pada anggota keluarganya, tetapi juga keterampilan melakukan hal tersebut. Dengan demikian, secara singkat didapatkan gambaran pengetahuan kader dan kondisi kesehatan gigi (DMF-T) keluarga dan faktor risiko terkait dengan perilaku kebersihan gigi mulut keluarga. Teori perilaku sebagai pendekatan dalam pencegahan penyakit gigi dan mulut dalam pemberdayaan masyarakat dengan menggunakan metode experiental learning ini dapat membantu kader kesehatan gigi dan mulut dalam pembelajaran berbasis pengalaman. Selain itu, hal tersebut juga memberikan manfaat, antara lain (a) pengalaman tersebut dapat memberikan hasil yang efektif pada kader (kepercayaan diri dan motivasi yang kuat pada kader serta self awareness kader dan keluarga nya) (b) pengalaman mendukung proses kognitif yang kuat pada kader (c) pengalaman mengajarkan materi (landasan ilmu, komunikasi, peran sebagai profesional untuk masa yang akan datang dapat diimplemtasikan oleh kader tidak hanya di lingkungan keluarga, tetapi juga lingkup yang lebih luas, yaitu di masyarakat dusun tersebut).

Pada pengabdian masyarakat ini, selain menerapkan teori tersebut juga didukung oleh teori Logic model. Logic model menjelaskan tahap-tahap dalam mengimplementasikan sebuah program, mulai dari input, output, outcomes dan goal dari program yang akan dicapai (Kemm dan Close, 1995). Pelaksanaan program pelatihan kader kesehatan gigi dan mulut di Dusun Pendul ini dirancang dengan tahapan pemberian bekal pengetahuan dan keterampilan mengukur status karies dengan pemeriksaan indeks karies DMF-T pada kader. Melalui pemberian pengetahuan dan keterampilan ini diharapkan akan timbul perubahan perilaku kader terhadap kesehatan gigi dan mulut. Pengetahuan dan kesadaran akan pentingnya gigi mulut meningkat pada tiap anggota keluarga. Selain itu, diperoleh data bahwa status karies gigi di lingkup keluarga kader sebagai acuan dalam pembuatan program yang bersifat promotif dan preventif sesuai dengan kebutuhan masayarakat Dusun Pendul. Dengan demikian, nantinya juga dapat berkolaborasi dan bekerja sama dengan pihak puskesmas setempat.

Logic model merupakan gambaran visual dari logika yang mendasari inisiatif yang direncanakan. Ini menunjukkan hubungan antara program sumber daya (input), kegiatan yang direncanakan (activities), dan perubahan yang diharapkan sebagai hasil (outcome). Model ini berguna bagi staf program dan pemangku kepentingan. Selain itu, model ini juga membantu 
mereka untuk berkomunikasi secara ringkas dan setuju dengan rencana keseluruhan. Ini merupakan sebuah logic model yang jelas dan sederhana yang direncanakan untuk status kesehatan suatu populasi (Fertman and Allensworth, 2010). Logic model ini memberikan gambaran alur logika program yang akan dijalankan dan memberikan penekanan pada hubungan yang paling penting antara action dan outcome. Logika untuk jalur dampak program dimulai dengan program promosi kesehatan yang menambahkan pencapaian tujuan perubahan yang akan menghasilkan perubahan pada faktor penentu hasil perilaku. Perubahan faktor penentu akan memengaruhi pencapaian hasil perilaku. Akhirnya, jika program memperoleh hasil perilaku, kesehatan dan kualitas hasil kehidupan akan membaik (Bartholomew et al., 2006).

\section{Simpulan}

Pemberdayaan masyarakat dengan menggunakan metode experiental learning dapat membantu kader kesehatan gigi dan mulut Dusun Pendul dalam pembelajaran berbasis pengalaman. Data status karies gigi yang sudah dihasilkan oleh para kader adalah data yang valid dan terukur. Data tersebut menunjukkan bahwa ada faktor risiko tertentu yang menyebabkan tingginya angka indeks DMF-T berdasarkan jenis kelamin dan umur.

\section{Ucapan Terima Kasih}

Tim pengabdi mengucapkan terima kasih kepada:

1. Rektor UMY yang telah memberi kesempatan untuk pelaksanaan pemberdayaan masyarakat.

2. Dekan Fakultas Kedokteran dan Ilmu Kesehatan dan Kaprodi Kedokteran Gigi UMY yang telah memberi kesempatan untuk pelaksanaan pemberdayaan masyarakat.

3. LP3M UMY yang telah memberi kesempatan dan bantuan untuk pelaksanaan pemberdayaan masyarakat.

4. Semua pihak yang tidak dapat tim pengabdi sebutkan satu per satu yang telah banyak membantu terselenggaranya pengabdian kepada masyarakat ini. Semoga Allah SWT berkenan melimpahkan pahala atas jasa semua pihak.

\section{Daftar Pustaka}

Adistie, F., Maryam, N.N., Lumbantobing, V.B. 2017. Pengetahuan Kader Kesehatan Tentang Deteksi Dini Gizi Buruk Bagi Balita. Dharmakarya: Jurnal Aplikasi Ipteks Untuk Masyarakat, 3(6): 173-177.

Bartholomew, L. K., Parcel, G.S., Kok, G., Gottilieb, N. H. 2006, Planning Health Promotion Programs: An Intervention Mapping Approach, 2nd Edition, John Wiley.

Borzak, L. 1981. Field study: A sourcebook for experiential learning. Sage Publications, Inc.

Dornan, T., Bundy, C. 2004. What can experience add to early medical education? Consensus survey. Bmj, 329(7470), 834. and Sons: San Francisco

Fertman, C.I., Allensworth, D.D. (n.d.). 2010. Heath Promotion Programs: From Theory to Practice, Joosey-Bass A Wiley Imprint : San Francisco.

Herjulianti, E., Indriani, T. S., Artini, S. 2001. Pendidikan Kesehatan Gigi. Jakarta: EGC. pp 5198

Hidayat, W., Nur'aeny, N., Wahyuni, I. 2016. Pembekalan Pengetahuan dan Kemandirian dalam Perawatan Kesehatan Gigi dan Mulut Masyarakat Desa Balingbing dan Desa Cidadap, Kecamatan Pengaden Barat, Subang. Dharmakarya: Jurnal Aplikasi Ipteks Untuk Masyarakat, 5 (1): 34-37. 
Kemenkes RI. (2013). Riset Kesehatan Dasar. Jakarta: Badan Penelitian dan Pengembangan Kesehatan.

Kemenkes RI. 2017. Profil Kesehatan Provinsi DIY. Yogyakarta: Dinas Kesehatan DIY. pp 74121.

Kemm, J., Close, A. 1995. Health Promotion: Theory and Practice. MacMillan Press Ltd: London.

Kidd, E., Bechal, S. J. 1991. Dasar-Dasar Karies dan Penanggulangannya. Jakarta: EGC. pp 530 .

Notoatmodjo, S. 2007. Promosi Kesehatan Dan Ilmu Perilaku. Jakarta: Rineka Cipta. pp 107108. 